\title{
White-sided dolphin metallothioneins: purification, characterisation and potential role
}

\author{
K. Das*, V. Jacob, J.M. Bouquegneau \\ Laboratoire d'Océanologie, B6 Université de Liège, B-4000, Liège, Belgium
}

Received 21 December 2000; received in revised form 24 May 2001; accepted 30 May 2001

\begin{abstract}
Metallothioneins (MTs) were characterised in the kidneys of a white-sided dolphin Lagenorhynchus acutus stranded along the Belgian coast, displaying high levels of cadmium $(\mathrm{Cd})$ and mercury $(\mathrm{Hg})$ in liver and kidney. The protein has two isoforms: MT-1 and MT-2. MT-1 binds $\mathrm{Cu}, \mathrm{Zn}, \mathrm{Hg}$ and $\mathrm{Cd}$, while MT-2 only binds $\mathrm{Zn}, \mathrm{Hg}$ and Cd. This suggests different metabolic functions for the two isoforms: MT-1 is mainly involved in Cu homeostasis; MT-2, which was fourfold more abundant than MT-1, detoxifies most of the accumulated cadmium. (c) 2002 Elsevier Science Inc. All rights reserved.
\end{abstract}

Keywords: Marine mammals; Lagenorhynchus acutus; White-sided dolphin; Heavy metals; Cadmium; Metallothioneins; Isoforms

\section{Introduction}

Since their first discovery by Margoshes and Vallee (1957), metallothioneins (MTs) have been detected studied in both prokaryotes and eukaryotes (Roesijadi, 1992, 1996) through more than 5000 research papers. MTs received their designation from their high metal and sulfur content. The mammalian forms are characterised by a low molecular mass of 6000-7000 Da, containing 6068 amino acid residues, among which 20 cysteines. MTs bind a total of 7 equivalents of bivalent metal ions. However, the natural function of metallothioneins remains elusive. Previous studies on structure, function and molecular regulation have established a central role for these small proteins

\footnotetext{
This paper was originally presented at a symposium dedicated to the memory of Marcel Florkin, held within the ESCPB 21st International Congress, Liège, Belgium, 24-28 July 2000.

*Corresponding author. Tel.: +32-4-3664829; fax: +32-43663325.

E-mail address: Krishna.Das@ulg.ac.be (K. Das).
}

in the homeostatic regulation of essential metals, including zinc $(\mathrm{Zn})$ and copper $(\mathrm{Cu})$, and detoxification of non-essential metals, such as mercury ( $\mathrm{Hg})$ or cadmium (Cd) (Klaassen et al., 1999). In order to understand the functions of MTs, the functionality and structure of each MT isoform need to be considered. Indeed, in various mammal organs, such as liver or kidney, two major isoforms, distinguishable by their charge, are present at low basal levels, MT-1 and MT-2 (Kägi, 1993). To date, however, no functional difference between the two isoforms has been firmly established (Moffat and Denizeau, 1997).

In the framework of heavy metal ecotoxicology, marine mammals appear as a choice material, since high levels of $\mathrm{Hg}$ and $\mathrm{Cd}$ can be naturally encountered in these animals (Das et al., in press). The potential role of metallothioneins in marine mammals has recently been reviewed by Das et al. (2000). It appears that very few characterisations of marine mammal metallothioneins have been attempted. The first attempt was realised on sea lion, Zalophus californianus, and kidney and liver 
of sperm whale, Physeter macrocephalus (Ridlington et al., 1981). Thereafter, MT I and II isolation and characterisation have been performed in the kidney of striped dolphin, Stenella coeruleoalba (Kwohn et al., 1986, 1988). More recently, Pillet et al. (2000) have described the presence of both isoforms in the blood leucocytes of the grey seal, Haliochoerus grypus.

In order to obtain a better understanding on the role of metallothioneins in the detoxification and dynamics of trace metals in marine mammals, detection, purification and trace metal content of white-sided-dolphin renal metallothioneins have been performed and compared with published data.

\section{Materials and methods}

The kidney and liver of an adult male whitesided dolphin, Lagenorhynchus acutus, found dead along the Belgian coast on 22 September 1999 were sampled and stored at $-20^{\circ} \mathrm{C}$. These dolphin tissues were remarkably fresh (Jauniaux, personal communication), allowing protein analysis. The renal tissue contained $78 \%$ water.

\subsection{AcA 54 chromatography}

A sample of 3-4 g of kidney was homogenised using an Ultra-Turrax homogeniser in $0.01 \mathrm{M}$ ammonium formate $(\mathrm{pH} 7.4)$ containing $10 \mathrm{mM}$ sodium azide and $0.01 \%$ dithiothreitol, and centrifuged at $26000 \times g\left(60 \mathrm{~min}, 4{ }^{\circ} \mathrm{C}\right)$. The supernatant was filtered on an AcA 54 gel column $(1.6 \times 64 \mathrm{~cm})$ at $4{ }^{\circ} \mathrm{C}$. Fractions were collected and the absorbance was read at 215, 254 and 280 nm.

\subsection{Heavy metals analysis and MT concentration assessment}

After adding nitric acid (65\%) to each fraction and to the pellet, homogenate and supernatant, all were slowly heated to $100{ }^{\circ} \mathrm{C}$ until digestion was complete. Samples were diluted using deionised water and filtered prior to heavy metal analysis ( $\mathrm{Zn}, \mathrm{Cu}$ and $\mathrm{Cd}$ ) by atomic absorption spectrophotometry (ICPS: ARL 3510). Hg was analysed by flameless atomic absorption (Perkin Elmer MAS50A) as described by Joiris et al. (1991). Quality control measurements for total mercury included replicate analysis, resulting in coefficients of vari- ation $<10 \%$ and analysis of certified material (DORM-1, NRC, Canada) as described by Debacker et al. (1997).

The $\mathrm{Hg}$ absolute detection limit is $10 \mathrm{ng}$, corresponding to $0.13 \mu \mathrm{g} \mathrm{g}^{-1}$ fresh weight (FW) for an average of $1.5 \mathrm{~g} \mathrm{FW}$. Detection limits for $\mathrm{Cu}$, $\mathrm{Cd}$ and $\mathrm{Zn}$ were $0.18,0.18$ and $0.17 \mu \mathrm{g} \mathrm{g}^{-1}$, respectively. Quality of the analyses was controlled through participation in an intercalibration program Quevauviller, 1997. Recovery rates ranged from 94, 97, 100 and $102 \%$ for $\mathrm{Hg}, \mathrm{Cu}, \mathrm{Zn}$ and $\mathrm{Cd}$, respectively. Metal concentrations are expressed as $\mu \mathrm{g}^{-1}$ FW. From the heavy metal analyses, the MT concentration was estimated considering that $\mathrm{Cu}$ occurs in the divalent form and that 1 mole MT with a molecular mass of 6800 Da typically binds seven divalent metal ions ( $7 \mathrm{~g}$ atom per MT mole) (Kägi, 1993; Kojima et al., 1999).

\subsection{DEAE Sephadex chromatography}

Anion exchange chromatography was performed according to Kwohn et al. (1986). Briefly, after ACA 54 gel chromatography, the fractions with low absorbance at $280 \mathrm{~nm}$ and high absorbance at $254 \mathrm{~nm}$ were pooled and lyophilised (VIRTIS, 12XL). To eliminate the $\mathrm{NaCl}$ resulting from the lyophilisation, the proteins were chromatographed on a Sephadex G25 medium column $(1.5 \times 28$ $\mathrm{cm})$. Metallothionein separation was performed on an anion-exchange Sephadex A25 $(1.6 \times 70 \mathrm{~cm})$ column equilibrated with $1 \mathrm{mM}$ Tris- $\mathrm{HCl}$ buffer ( $\mathrm{pH}$ 8.6). Elution was carried out in gradient mode with 1-250 mM Tris- $\mathrm{HCl}$ buffer, $\mathrm{pH}$ 8.6.

The ultraviolet spectra of renal MT- 1 and MT-2 were recorded using the highest resolution of 0.2 $\mathrm{nm}$. DEAE Sephadex chromatography, Cd, Zn and $\mathrm{Cu}$ analyses, and UV spectral measurements were carried out in triplicate.

\section{Results}

AcA-54 gel chromatography (Fig. 1a) of the supernatant reveals a large band of metal $(\mathrm{Zn}, \mathrm{Cd}$, $\mathrm{Cu}$ ) in the $10-\mathrm{kDa}$ region of the profile, consistent with the presence of metallothioneins. This metal peak is associated with high absorbance at $254 \mathrm{~nm}$ and low absorbance at $280 \mathrm{~nm}$, related to the lack of aromatic amino acids of these proteins. This metallic peak shows remarkably high temperature 
(a)

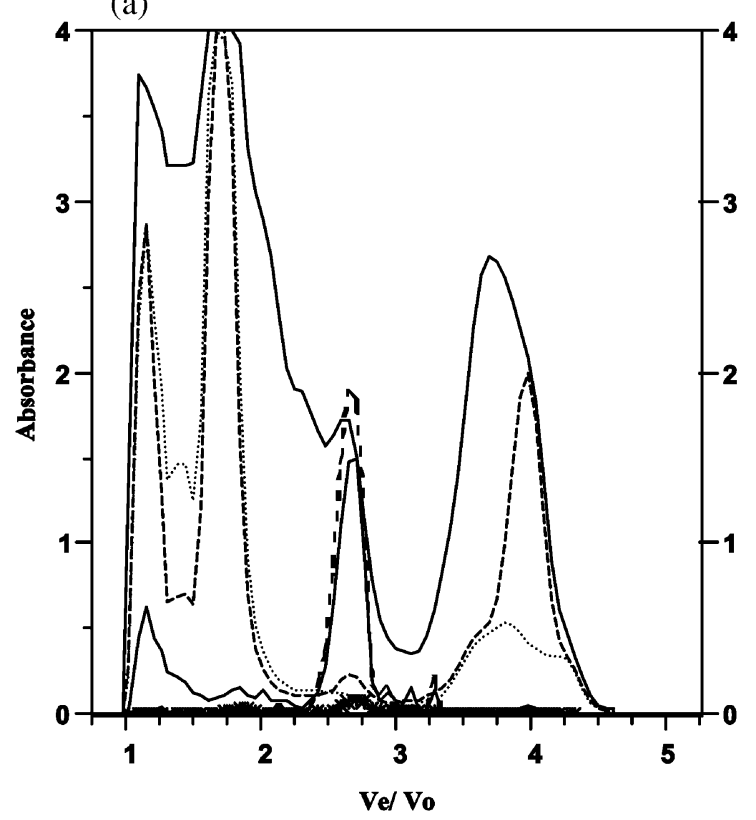

(b)

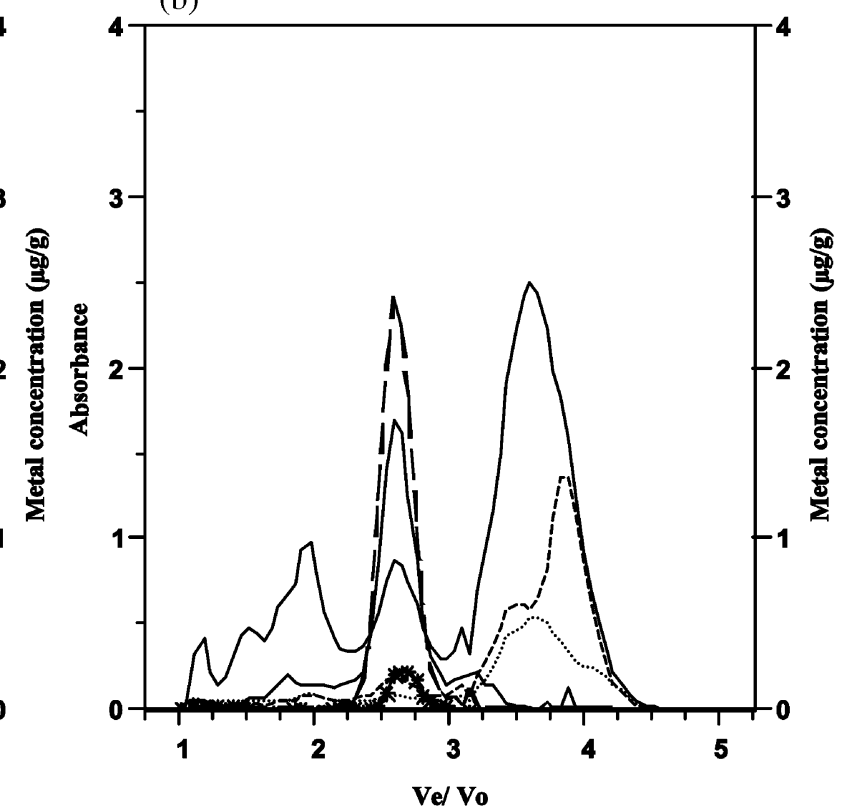

Fig. 1. Elution profile on AcA 54 column of the water-soluble fraction extracted from kidney of the white-sided dolphin Lagenorhynchus acutus (a) before and (b) after $89{ }^{\circ} \mathrm{C}$ heat treatment of the cytosolic fraction. The three types of bold lines represent the metal concentrations $(-, \mathrm{Zn} ;--, \mathrm{Cd} ; * *, \mathrm{Cu})$ of the fractions. The normal lines represent the protein absorption $(-, 215 ;--, 250 ; \ldots, 280 \mathrm{~nm})$; Ve, elution volume; Vo, void volume of the column; mean volume per fraction, $2 \mathrm{ml}$.

tolerance after a 3 -min heat treatment at $89{ }^{\circ} \mathrm{C}$ followed by centrifugation (Fig. 1b).

Table 1 shows the metal $(\mathrm{Cd}, \mathrm{Zn}, \mathrm{Hg}, \mathrm{Cu})$ distribution in the insoluble and soluble fractions, including the metals bound on high molecularweight-proteins, metallothionein-like proteins and smaller molecules. High cadmium concentrations were found in the kidney (more than $12 \mu \mathrm{g} \mathrm{g}^{-1}$ FW) and liver ( $5 \mu \mathrm{g} \mathrm{g}^{-1} \mathrm{FW}$; data not shown). Almost $60 \%$ of the total Cd, $30 \%$ of the total $\mathrm{Zn}$ and $12 \%$ of the total copper are bound to cytosolic metallothioneins. The amount of metallothionein in kidney was calculated from the metal content, assuming that the protein was fully saturated (seven equivalent of divalent ions or $7 \mathrm{~g}$ atom per MT mole) with a molecular mass of $6800 \mathrm{kDa}$. A metallothionein concentration of $172 \mu \mathrm{g} \mathrm{g}^{-1} \mathrm{FW}$ was calculated. After DEAE Sephadex A25 chromatography, the level of both isoforms estimated from trace metal data differed (Fig. 2): the MT-2 concentration was four-fold higher than that of MT-1.

Fig. 2 shows the elution profile of the DEAE Sephadex A-25 ion exchange chromatography. The

Table 1

$\mathrm{Zn}, \mathrm{Cd}, \mathrm{Cu}$, and $\mathrm{Hg}$ renal content in the insoluble fraction (pellet), cytosol (soluble proteins) containing the high molecular-weightproteins (HMWP), metallothioneins (MTs) and lower molecular-weight-proteins (LMWP)

\begin{tabular}{|c|c|c|c|c|c|c|}
\hline \multirow[t]{3}{*}{ Metal } & \multicolumn{6}{|c|}{ Metal content $\left(\mu \mathrm{g} \mathrm{g}^{-1} \mathrm{FW}\right)$} \\
\hline & \multirow[t]{2}{*}{ Total } & \multirow{2}{*}{$\begin{array}{l}\text { Insoluble } \\
\text { fraction } \\
\text { (pellet) }\end{array}$} & \multirow{2}{*}{$\begin{array}{l}\text { Cytosol } \\
\text { (supernatant) }\end{array}$} & \multicolumn{3}{|c|}{ Protein type } \\
\hline & & & & HMWP & MTs & LWMP \\
\hline$\overline{\mathrm{Zn}}$ & $19(100 \%)$ & $8(42 \%)$ & $11(58 \%)$ & 4 & $6.6(35 \%)$ & 0.7 \\
\hline $\mathrm{Cd}$ & $12(100 \%)$ & $3(25 \%)$ & $9(75 \%)$ & $<0.2$ & $8.30(71 \%)$ & 0.3 \\
\hline $\mathrm{Cu}$ & $2.2(100 \%)$ & $1.6(72 \%)$ & $0.6(18 \%)$ & 0.14 & $0.4(18 \%)$ & $<0.2$ \\
\hline $\mathrm{Hg}$ & $2(100 \%)$ & $1.5(75 \%)$ & $0.6(25 \%)$ & ND & ND & ND \\
\hline
\end{tabular}

$\mathrm{ND}$, not determined. 
profile reveals three metal-containing fractions, indicating that the MT was resolved into two isoproteins along the $\mathrm{NaCl}$ gradient. The first metal-containing fraction (labelled I in the figure) did not bind to the column matrix and was eluted with $1 \mathrm{mM}$ Tris- $\mathrm{HCl}(\mathrm{pH} \mathrm{8.6)}$ before the gradient started. This peak contains $\mathrm{Zn}, \mathrm{Cd}$ and $\mathrm{Hg}$. The last two fractions were, in accordance with earlier experiments on mammalian liver, kidney and intestine, designated as MT-1 and MT-2 (Kwohn et al., 1986; Suzuki, 1991; Moffat and Denizeau, 1997). $\mathrm{Hg}$ concentrations were determined in pooled fractions $(0.016$ and $0.03 \mu \mathrm{g}$ atom for MT- 1 and MT2 , respectively).

Furthermore, we observed that the metal composition of white-sided dolphin isometallothioneins varied in the different isoforms: MT-1 contained $\mathrm{Zn}, \mathrm{Cd}, \mathrm{Hg}$ and $\mathrm{Cu}$, while MT-2 contained $\mathrm{Zn}, \mathrm{Cd}$ and $\mathrm{Hg}$. Copper could not be detected in the second isoform (Table 2).

The ultraviolet spectrum reveals very low
Table 2

The molar ratio of metal/thionein in striped (after Kwohn et al., 1986) and white-sided dolphins (mean \pm standard deviation of the measure, this work; $n=$ number of replicates)

\begin{tabular}{llll}
\hline & \multicolumn{2}{l}{$\begin{array}{l}\text { Metal/thionein ratio } \\
\left(\mathrm{g} \text {-atoms } 6000 \mathrm{~g}^{-1}\right)\end{array}$} & $n$ \\
\cline { 2 - 3 } & $\begin{array}{l}\text { Striped } \\
\text { dolphin }\end{array}$ & $\begin{array}{l}\text { White-sided } \\
\text { dolphin }\end{array}$ & \\
\hline$M T-1$ & & & \\
$\mathrm{Cd}$ & 2.41 & $2.57 \pm 0.3$ & 3 \\
$\mathrm{Hg}$ & 0.06 & 0.39 & 1 \\
$\mathrm{Zn}$ & 2.09 & $2.47 \pm 0.2$ & 3 \\
$\mathrm{Cu}$ & 0.98 & $1.82 \pm 0.7$ & 3 \\
$M T-2$ & & & \\
$\mathrm{Cd}$ & 2.93 & $2.99 \pm 0.4$ & 3 \\
$\mathrm{Hg}$ & 0.04 & 0.22 & 1 \\
$\mathrm{Zn}$ & 2.86 & $3.88 \pm 0.5$ & 3 \\
$\mathrm{Cu}$ & 0.16 & $<0.04$ & 3 \\
\hline
\end{tabular}

absorbance at $280 \mathrm{~nm}$ and a shoulder at $254 \mathrm{~nm}$, mainly for MT-2 (Fig. 3). The absorbance values

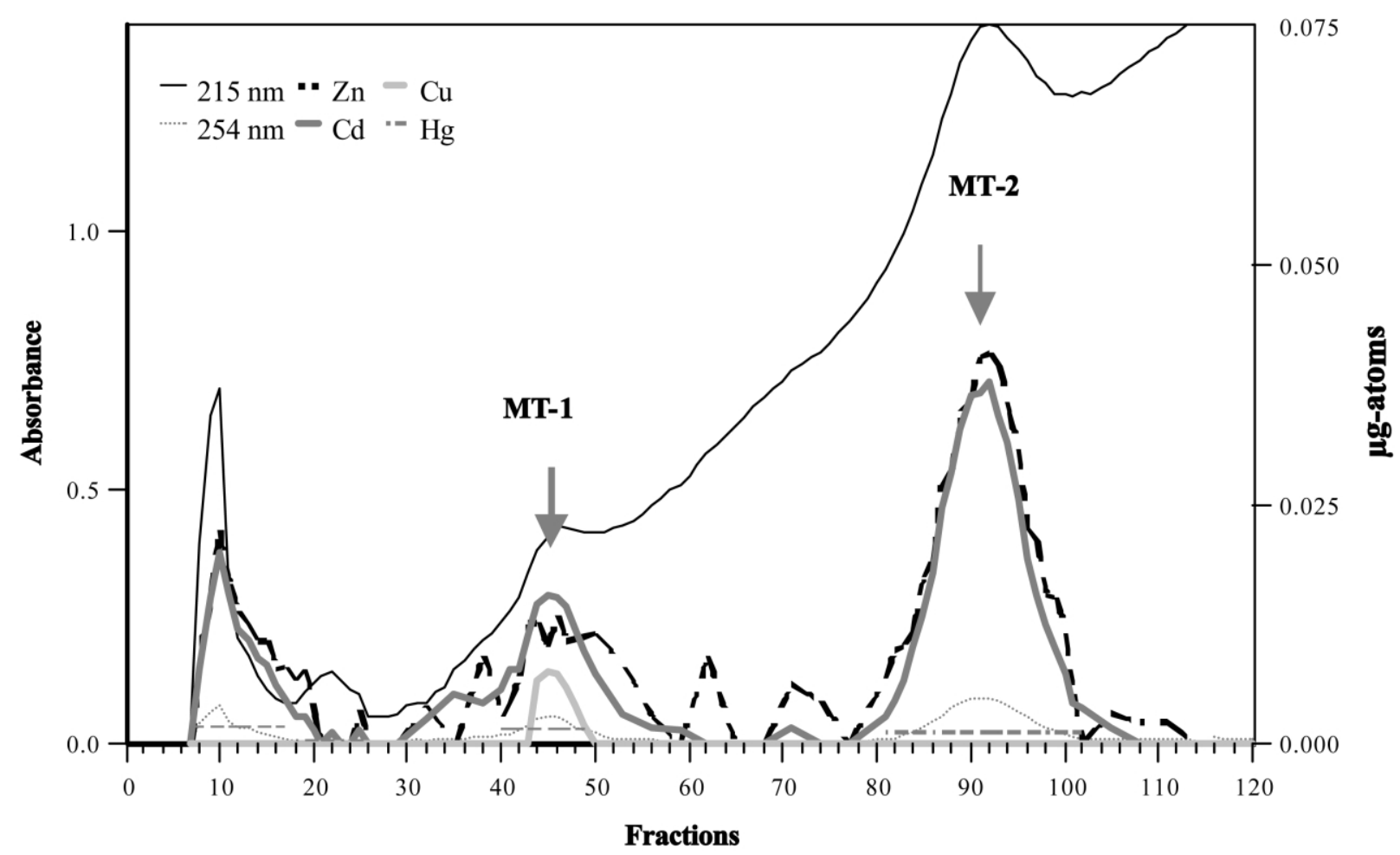

Fig. 2. DEAE Sephadex A-25 chromatography profile of white-sided-dolphin metallothioneins. Pooled and concentrated metallothionein fractions from AcA 54 column were applied to a DEAE Sephadex A-25 column. The three types of bold lines represent the $\mathrm{Zn}, \mathrm{Cd}$, and $\mathrm{Cu}$ concentrations of the fractions. Metal concentrations are expressed in $\mu \mathrm{g}$-atoms (concentration expressed in $\mu \mathrm{g} \mathrm{g}^{-1}$ divided by the respective metal atomic mass). The horizontal dotted lines represent the $\mathrm{Hg}$ concentration in the three pooled fractions. The normal lines represent the 215- and 250-nm protein absorption. 


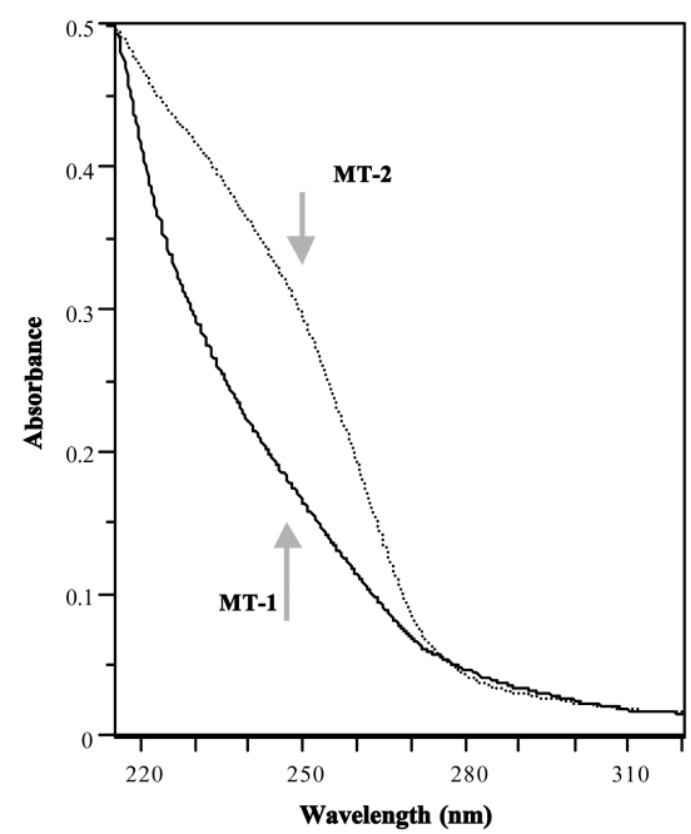

Fig. 3. Ultraviolet spectrum of white-sided dolphin MT-1 and MT-2.

at 230, 250, 270, and $310 \mathrm{~nm}$ reflect $\mathrm{Zn}-\mathrm{S}, \mathrm{Cd}-\mathrm{S}$, $\mathrm{Cu}-\mathrm{S}$ and $\mathrm{Hg}-\mathrm{S}$ binding.

\section{Discussion}

Cadmium is known to preferentially accumulate in the kidneys, bound in large amounts to MTs, which also contain $\mathrm{Zn}$ and $\mathrm{Cu}$. Renal and hepatic $\mathrm{Cd}$ concentrations measured in the male whitesided dolphin kidney are high (Table 1). Indeed, the hepatic $\mathrm{Cd}$ concentration is 10 -fold higher than the $0.5 \mu \mathrm{g} \mathrm{g}^{-1} \mathrm{FW}$ previously measured in the liver of an adult white-sided dolphin from the US Atlantic coast (Kuehl et al., 1994).

Of the renal cadmium, $81 \%$ was found in the soluble fraction of the tissue, mostly bound to low-molecular-weight, soluble and heat-stable proteins (Fig. 1, Table 1) with high absorbance at $254 \mathrm{~nm}$ and a lack of absorbance at $280 \mathrm{~nm}$, in agreement with MT-specific features. The heat tolerance of these proteins is remarkable and implies that a single dose of $\mathrm{Cd}, \mathrm{Zn}, \mathrm{Cu}$ and $\mathrm{Hg}$ in the heat-treated supernatant, followed by centrifugation, could allow the determination of the MT-bound metals, and hence the renal MT con- centrations. Complementary studies on other species have been carried out in our laboratory to test the accuracy of such a method to quantify MTs in marine mammals.

Mercury is preferentially distributed in the insoluble fraction of the kidney (pellet, Table 1), probably resulting from the well-known formation of tiemannite $(\mathrm{HgSe})$ in marine mammal liver and kidney (Das et al., 2000; Das et al., in press).

Mammal kidney metallothioneins consist of two isoforms, MT-1 and MT-2, named in the order of their elution from an anion-exchange column (Suzuki, 1991). The resolution of white-sided dolphin renal MT into two isoproteins (MT-1 and MT-2, Fig. 2) by ion exchange chromatography corroborates the observations made on kidney and liver MT of monkey (Paliwal et al., 1982, 1986), human (Hellemans et al., 1999) and striped dolphin (Kwohn et al., 1986).

$\mathrm{Cd}, \mathrm{Zn}$ and $\mathrm{Hg}$ bound to both isoforms, while copper was not detected on MT-2. These results are consistent with a previous study on striped dolphin, Stenella coeruleoalba, which showed that MT-2 bound $\mathrm{Cu}$ in lower amounts than MT-1 (Kwohn et al., 1986; Table 2). These results seem to indicate a specific role of renal MT-1 in copper homeostasis, copper being an essential metal involved in many enzymatic processes (Eisler, 1997).

MT-2 is the major isoform present in whitesided dolphin kidney, with a MT-2/MT-1 ratio concentration equal to 4.2. A ratio of 16 has been measured in striped dolphin kidney and 6.2 in equine kidney (Kwohn et al., 1986). However, it is worth noting that Wagemann and Hobden (1986) reported MT-1 as the major form of MTs in the liver and kidney from a narwhal. In fact, the relative abundance of each isoform can differ according to species, age, tissue and the nature of the inducers (Moffat and Denizeau, 1997). The higher MT-2 concentration probably results from a difference in the rate of synthesis of hepatic MT1 and MT-2, which leads to a greater and more prolonged induction of MT-2 following administration of trace metals (Lehman-McKeeman et al., 1991) and a faster degradation rate of MT-1 compared to MT-2 (Mehra and Brenmer, 1985). As a whole, this leads to a more important role of MT-2 in the sequestration of $\mathrm{Cd}$. 


\section{Conclusions}

White-sided dolphin metallothioneins display two renal isoforms, MT-1 and MT-2, characterised by different metabolic functions in relation to copper cellular homeostasis (MT-1) and cadmium detoxification (MT-2). MTs appear to play a minor role in the binding and detoxification of $\mathrm{Hg}$ by marine mammals. Moreover, after appropriate heat treatment, trace metals measured in the supernatant were those bound to MTs, leading to a potential rapid and simple method to quantify these proteins in marine mammal tissues. Further experiments are needed to test the suitability of this method to others tissues and species.

\section{Acknowledgments}

The authors are grateful to Thierry Jauniaux, Jan Haelters and Jan Tavernier (Marine Animal Research and Intervention Network) for providing the samples. Thanks also to Renzo Biondo and Nicole Gérardin for their valuable technical assistance. The manuscript was improved by the comments of an anonymous reviewer and Miss Christina Beans. Thanks to Sylvie Gobert, Virginie Debacker and Gilles Lepoint for their helpful advice and remarks. Krishna Das has received a grant from FRIA (Fonds pour la Recherche dans l'Industrie et dans l'Agriculture). The study was supported by a grant from the Belgian Office for Scientific, Technical and Cultural Affairs (Contract $\mathrm{MN} / \mathrm{DD} / 50)$.

\section{References}

Das, K., Debacker, V., Bouquegneau, J.M., 2000. Metallothioneins in marine mammals: a review. Cell. Mol. Biol. 46, 283-294.

Das, K., Debacker, V., Pillet, S., Bouquegneau, J.M. Heavy metals in marine mammals. In: Toxicology of Marine Mammals. Taylor and Francis, Washington, DC, in press.

Debacker, V., Holsbeek, L., Tapia, G., et al., 1997. Ecotoxicological and pathological studies of common guillemots Uria aalge beached on the Belgian coast during six successive wintering periods (1989-90 to 1994-95). Dis. Aquat. Org. 29, 159-168.

Eisler, R., 1997. Copper Hazards to Fish, Wildlife and Invertebrates: A Synoptic Review, Biological Science Report USGS/BRD/BSR-1997-0002, US Geological Survey, Biological Resources Division, 98 pp.

Hellemans, G., Soumillion, A., Proost, P., et al., 1999. Metal- lothioneins in human kidney and associated tumors. Nephron 83, 331-340.

Joiris, J.C., Holsbeek, L., Bouquegneau, J.M., Bossicart, M., 1991. Mercury contamination of the harbour porpoise Phocoena phocoena and others cetaceans from the North Sea and the Kattegat. Water Air Soil Pollut. 56, 283-293.

Kägi, J.H.R., 1993. Evolution, structure and chemical activity of class I metallothioneins. An overview. In: Suzuki, K.T., Imura, N., Kimura, M. (Eds.), Metallothionein III, Birkhäuser Verlag, Basel, Switzerland pp. 29-55.

Klaassen, C.D., Liu, J., Choudhuri, S., 1999. Metallothionein: an intracellular protein to protect against cadmium toxicity. Annu. Rev. Pharmacol. Toxicol. 39, 267-294.

Kojima, Y., Binz, P.-A., Kägi, J.H.R., 1999. Nomenclature of metallothionein: proposal for a revision. In: Klaassen, C.D. (Ed.), Metallothionein IV, Birkhäuser Verlag, Basel pp. 3-6.

Kuehl, D.W., Haebler, R., Potter, C., 1994. Coplanar and metal residues on dolphins from the US Atlantic coast including Atlantic bottlenose obtained during 1987-88 mass mortality. Chemosphere 28, 1245-1253.

Kwohn, Y.T., Okubo, A., Hirano, H., Kagawa, H., Yamazaki, S., Toda, S., 1988. Primary structure of striped dolphin renal metallothionein II. Agric. Biol. Chem. 52, 837-841.

Kwohn, Y.T., Yamazaki, S., Okubo, A., Yoshimura, E., Tatsukawa, R., Toda, S., 1986. Isolation and characterization of metallothionein from kidney of striped dolphin, Stenella coeruleoalba. Agric. Biol. Chem. 50, 2881-2885.

Lehman-McKeeman, L.D., Kershaw, K.C., Klaassen, C.D., 1991. Species differences in metallothioneins regulation: a comparison of the induction of isometallothioneins in rats and mice. In: Klaassen, C.D., Suzuki, K.T. (Eds.), Metallothionein in Biology and Medicine, CRC Press, Boca Raton, FL pp. 121-131.

Margoshes, M., Vallee, B.L., 1957. A cadmium protein from equine kidney cortex. J. Am. Chem. Soc. 79, 4813-4814.

Mehra, R.K., Brenmer, I., 1985. Studies on the metabolism of rat liver copper-metabolism. Biochem. J. 227, 903-908.

Moffat, P., Denizeau, F., 1997. Metallothionein in physiological and physiopathological processes. Drug Metab. Rev. 29, 261-307.

Paliwal, V.K., Kohli, K.K., Sharma, M., Nath, R., 1986. Purification and characterization of metallothionein from liver of cadmium-exposed rhesus monkeys (Macaca mulatta). Mol. Cell. Biochem. 71, 139-147.

Paliwal, V.K., Lyall, V., Prasad, R., Gulati, S., Sharma, M., Nath, R., 1982. Purification and characterization of monkey kidney cadmium metallothionein and its selenium binding properties. Biochem. Int. 4, 399-408.

Pillet, S., Fournier, M., Bouquegneau, J.M., Cyr, D., 2000. Modulation by zinc and estradiol of metallothionein levels in grey seal peripheral blood leukocytes. Comp. Biochem. Physiol. A 126 (Abstract), 121.

Quevauviller, P., 1997. The QUASIMEME Project from a European Union viewpoint. Mar. Pollut. Bull. 35, 140-145. Ridlington, J.W., Chapman, D.C., Goeger, D.E., Whanger, P.D., 1981. Metallothionein and $\mathrm{Cu}-$ chelatin: characteriza- 
tion of metal-binding proteins from tissues of four marine animals. Comp. Biochem. Physiol. 70B, 93-104.

Roesijadi, G., 1992. Metallothioneins in metal regulation and toxicity in aquatic animals. Aquat. Toxicol. 22, 81-114.

Roesijadi, G., 1996. Metallothionein and its role in toxic metal regulation. Comp. Biochem. Physiol. 113C, 117-123.
Suzuki, K.T., 1991. Purification of vertebrate metallothioneins. Methods Enzymol. 205, 252-263.

Wagemann, R., Hobden, B., 1986. Low molecular weight metalloproteins in tissues of the narwhal (Monodon monoceros). Comp. Biochem. Physiol. 84C, 325-344. 